tive method, involving computation, would be to use a tristimulus colorimeter separately with Illuminant $C$ and with an ultra-violet source, afterwards combining the readings to predict the tristimulus eoefficients that would be obtained with the ideal illuminant. The interpretation of these results is complicated by the fact that the eye is willing to accept a change in chromaticity towards blue and an increase in luminance as being equally satisfying. It has been found experimentally, in the comparison of green-shade and violet-shade whiteners, that the former have a greater lightening effect and the latter a greater blueing effect, and that these two effects can be comparable perceptually ${ }^{5}$.

One of the disadvantages which may attend the use of optical whitening agents, namely, poor stability of the white due to the poor fastness to light of most of these agents, has already been mentioned. If, for example, articles so treated are exposed in a shop window, the parts receiving most light might become appreciably yellower in shade than the other parts. Poor fastness to light is not of much significance in laundering. Here the greater danger is that of excessive build-up of the agent in successive washes with the resultant formation of an objectionable tint ; careful choice of the fluorescent agent is necessary to avoid this.

Some fluorescent agents are known to cause a yellowish discoloration, particularly with wool, after a comparatively short exposure to light and, in conse- quence, a dyer may be accused unjustly of using dyes of poor light-fastness when the fault really lies with the optical whitening agent employed in laundering. Quite apart from fading, or the development of an objectionable tint on exposure to light, there is an additional hazard; some of the agents available can cause the development of a pink or green shade on storage, even in the dark.

It will be seen, therefore, that the widespread use of fluorescent whitening agents has not proved to be an entirely unmixed blessing. Their introduction has brought in its wake serious new problems for the dyer and additional hazards for the retailer and consumer. No doubt many of the difficulties that have already arisen have been due to misuse of the agents, but it is already abundantly clear that this particular incursion of science into textile technology will have to be brought under careful control. In particular, it cannot be too strongly emphasized that the use of these agents cannot in any way be regarded as a substitute for the removal of natural colouring matter by conventional bleaching methods.

Fluorescent brightening agents was the subject of a meeting of the West Riding Section of the Society of Dyers and Colourists, held at Bradford on March 13. "Nene Verfahren in der Tecbnik der chemischen Veredlung der
Textilfasern", 2, 654 (I. Diserens, Basle, 1953).

" "Textilveredlung", 8, 29 ( $Q$. Moier, Berlin, 1956).

Delecluse, C., Teintex, 21, No. 4, 271 ; No. 5, 363 (1956).

- Dorset, B. C. M., Text. Mfr., 80, 254 (1954).

Allen, E., J. Opt. Soc. Amer., 47, 933 (1957).

\title{
THE GLASGOW MEETING OF THE BRITISH ASSOCIATION
}

$\mathrm{T}$ HE British Association for the Advancement of Science will hold its annual meeting this year in Glasgow during August 27-September 3. The Association is too well known to readers of Nature to require introduction: suffice it to say that the City and University of Glasgow are very pleased to welcome its return after an absence of thirty years, and to place at the disposal of its members the greatly increased facilities for the furtherance of scientific and technological studies which have boen built up in the intervening period. Such of the members as recall the meeting in 1928 will see much visible evidence of the advances of science since their last visit.

The general pattern of events in Glasgow will be similar to that of the Association's meetings at other centres in recent years. The mornings will be devoted to lectures and discussions for which the members attending will divide into their various groups and sub-groups. The afternoons will be largely given over to excursions and educational visits, and the evenings to social functions. For all these purposes, most of the available space in the University has been requisitioned. An outline of the topics proposed for the morning sessions is given in the preliminary programme of the meeting (obtainable from the Secretary, British Association for the Advancement of Science, Burlington House, London, W.1).

The Glasgow meeting will have one important advantage over those of recent years, in that the University site on Gilmorehill is compact and members will have little difficulty either in finding their way there or, when there, in locating the lecture theatres or other meeting rooms. Catering will, likewise, be simplified, as the Unions and the adjacent College of Domestic Science have generously put their facilities at the Association's disposal. Plans have been made for providing a mid-day meal for the 3,000 or so visitors who are expected to attend the meeting, and for the supply of mid-morning coffee.

The preliminary programme referred to above also gives details of the excursions and visits offered to members by the Local Committee. These are many and varied and cater for all interests, perhaps especially for the geologists, geographers and engineers who, in view of Glasgow's situation and character, are most likely to find the 1958 meeting a memorable one. A well-chasen series of excursions will cover most of the important aspects of the geology and geography of the west and south of Scotland. On the engineering side, a wide range of visits to industrial premises and research stations has been planned, by courtesy of the firms and Government departments concerned. Both heavy and light industry will be represented. In addition to thase excursions and visits which are more or less clearly linked to some aspect of science or its applications, facilities will be offered for visits to local besuty spots, including Loch Lomond, the Trossechs, Arran and the Firth of Clyde.

The meeting will provide an occasion for a number of exhibitions of scientific interest, by the scientific societies of Glasgow and district, the Geological Society of Glasgow (which celebrates-most appropriately - the centenary of its foundation this year) and others. The oil companies will mount a major exhibition, "Geology in the Petroleum Industry", in 
the Royal College of Science and Technology. Of interest to schoolchildren and their parents will be an exhibition, "Science in Schools", arranged by the local officers of the Science Masters' Association.

A novel feature of the 1958 meeting will be a series of lecture-demonstrations for school-children given by eminent scientists. The publicity given to this innovation, coinciding as it did with a local schoolchildren's exhibition and the British Association's own recent conference on "Science in Schools", may have created the impression locally that the Association's interests are turning exclusively to the advancement of science among school-children. There is no doubt, however, that it has given a welcome fillip to the publicity campaign undertaken by the Local Committee on the Association's behalf, and that the progress of the 'Junior British Association', as it has come to be known, will be followed with much interest.
The Local Committee has not neglected the lighter side. A dinner or similar function is planned for each section of the Association, while a large-scale reception for the members will be given by the Corporation in the City Chambers and in the Art Gallery and Museum, Kelvingrove. Other social functions will include a reception arranged by the British Council for overseas guests, and a reception promoted by the scientific societies of Glasgow and district for visitors sharing their interests. On the evening of Sunday, August 31, a symphony concert will be given by the B.B.C. Scottish Orchestra in St. Andrew's Hall.

The Association meets in Glasgow under the presidency of Sir Alexander Fleck, chairman of Imperial Chemical Industries, Ltd., and himself a distinguished graduate of the University. He will address the inaugural meeting of the Association in St. Andrew's Hall on August 27 on "Science and Business : a Balanced Partnership".

\section{OBITUARIES}

\section{Prof. Charles F. Brooks}

The world of meteorology suffered a grievous loss in the death of Charles Franklin Brooks on January 8. Prof. Brooks will be remembered for his long tenure as director of the Blue Hill Meteorological Observatory of Harvard University and for his many contributions to climatology, synoptic meteorology and methods of observation. His services with several commissions of the World Meteorological Organiza. tion and its predecessor, the International Meteorological Organization, made him a rather frequent visitor to Great Britain and the Continent. Most recently he served on the committee that produced the new International Cloud Atlas.

Prof. Brooks was born on May 2, 1891, in St. Paul, Minnesota. He was educated at Harvard University, which awarded him the A:B. in 1911, the A.M. in 1912 and the Ph.D. in climatology in 1914. While still a student at Harvard he served as an assistant at Blue Hill, thus becoming familiar with the Observatory where he was later to spend much of his professional career. After four years in the U.S. Department of Agriculture and as an instructor in geography at Yale University, Prof. Brooks began his meteorological career in the U.S. Weather Bureau, where for two years he was editor of the Monthly Weather Review. In 1921, he was appointed associate professor (later professor) of meteorology and climatology at Clark University, Worcester, Massachusetts. In 1931, he assumed the post of professor of meteorology and director of the Blue Hill Meteorological Observatory at Harvard. He remained at Blue Hill until his retirement $a$ few months before his death.

Prof. Brooks played a leading part in the establishment of the American Meteorological Society in 1919. He served the Society with untiring devotion as its secretary from its inception until 1954, editor of its Bulletin for seventeen years and as treasurer in 1922. Through the lean years of the 'twenties and the early 'thirties Prof. Brooks almost single-handedly kept the Society alive. Fortunately, he lived to see the Society become the largest and most active meteorological society in the world. He was a member of many other societies, including the Royal Meteorological Society, and served as president of the Association of American Geographers in 1947.
Those of us who knew Prof. Brooks will remember him most for his warmth, kindness and humanity. Throughout his life he gave freely of his time and resources to the many who sought his assistance. Many American meteorologists were guided and assisted early in their careers by him. His charitable acts extended far beyond the realms of meteorology, and there is little doubt that his concern for his fellow-men acted as a detriment to his own soientific activities.

Prof. Brooks was one of our most effective spokesmen to the general public. He ably presented the case for meteorology and meteorologists through radio broadcasts, the Press, many talks and his book, "Why the Weather". He also kept his representatives in the United States Congress informed on pending legislation that involved meteorological questions. He was a staunch and effective supporter of the United States Weather Bureau.

We will sorely miss our friendly colleague in the years to $\operatorname{com} \theta$, but his influence will continue through his many good works and the example he set for his legion of friends. HENRY G. HOUGHTON

\section{Mr. Arthur Earland}

Mr. Arthur Eariand died on March 27 at Broughty Ferry, Dundee, at the age of ninety-one. Internationally known in the field of marine zoology, in particular for his contributions to our knowledge of the Foraminifera, he was by profession a Civil servant and employed in the Post Office Savings Bank Department. By all standards he was successful in both his professional and amateur ventures, and his name is a worthy addition to any list of eminent amateur naturalists of the past.

$\mathrm{He}$ was born at Lewisham on November 3, 1866, and received his only formal education at a local school. He declined a university education, feeling this would lead him to school-teaching as a career, and entered the Civil Service in 1885 as a 'boy clerk'. Here he stayed in various capacities until 1926, when ill-health caused his premature retirement. He had then been three years as an assistant controller, and during his service he was the person chiefly responsible for drafting the Stork Register Regulations, as well 